\title{
On the Boate Kiss Fire and the Brazilian Safety Legislation - What we can learn
}

\author{
Henrique Costa Braga - Gray Farias Moita \\ Centro Federal de Educação Tecnológica de Minas Gerais, CEFET-MG, Post-Graduate \\ Program in Mathematical and Computational Modelling, Belo Horizonte, Brazil, \\ E-mail: bragaseg@yahoo.com.br \\ E-mail: gray@dppg.cefetmg.br
}

Received: 31 May 2016 / Accepted: 4 December 2017

DOI: $10.17815 / \mathrm{CD} .2017 .12$

\begin{abstract}
Brazil was recently the scenario of a great tragedy in the fire at Kiss nightclub, where 242 people were killed. The starting point of the fire was the use of a pyrotechnic device over an acoustic coating made of polyurethane foam. The causalities were caused mainly by asphyxia and inhalation of toxic gases in a very fast smoke expansion. However, several additional causes contributed to the amount of damage and human losses. The accident investigations emphasized the necessity to discuss details in the applicable Brazilian legislation. In this work, the tragedy of Kiss nightclub is presented and the some of their main aspects discussed. The Brazilian standard (ABNT NBR 9077) to determine the dimension of the emergency exits is also presented. It was found that, in spite of the configurations of Kiss nightclub have had a fundamental role in tragedy, the current Brazilian standard was not appropriate for the design of such an environment and should not have been used. Moreover, clear and more rigorous standards also need to be further discussed, particularly for non-adaptive situations. At the end, some considerations are made in order to improve the general fire prevention standards about dimensioning of emergency exits.
\end{abstract}

Keywords Boate Kiss · Kiss nightclub · safety legislation · fire · evacuation · nightclub · Brazil · emergency exit · smoke · ABNT NBR 9077

\section{Introduction}

In January 27, 2013, at around 3:15AM, a great tragedy occurred in Brazil, the fire in Kiss nightclub (the official name of the enterprise was "Santo Entretenimentos Ltda", but is was commonly know as Boate Kiss), in the city of Santa Maria. This fire killed 242 
people, most of them young university students, and more than six hundred persons were also injured, many seriously. Various of these injured people will still be needing medical care for a long period of time as yet [1]. This was the second biggest Brazilian official tragedy by fire (the largest in the last 50 years), only overcome by the fire in the Gran Circus Norte-Americano ${ }^{1}$, and the third biggest worldwide fire tragedy in a nightclub ${ }^{2}$.

Repeatedly, tragedies by fire in environments such as nightclubs (even in small ones) have been occurring $[3,4]$, thus these environments can be considered critical in terms of safety. Other nightclub tragedies (The Station nightclub - Rhode Island - USA, in 2003 [5, 6], or República Cromañon - Buenos Aires - Argentina, in 2004) presented several similarities with what happened in Boate Kiss [7]. Unfortunately, the knowledge acquired in these earlier tragedies has been neglected by many, including the authorities [8]. The accident in Boate Kiss had great repercussion in the world media, with some authors highlights and much controversy [9-11].

The starting point of the fire was the use of a cheap pyrotechnic device over an acoustic coating made of a kind of polyurethane foam. The causalities were caused mainly by asphyxia and toxic gases inhalation, such as hydrogen cyanide ( $\mathrm{HCN})$ or carbon monoxide (CO), from the smoke generated by the burning foam $[12,13]$. In spite of the causative main factor, the investigations pointed out that several additional causes contributed to the amount of damage and human casualties [14-16]. Therefore, the necessity to discuss many of the crucial technical details in the applicable Brazilian safety legislation was also emphasized in some reports $[7,17,18]$.

There exits a lot of available information about the Boate Kiss tragedy. However the data are very scattered, most of them in Portuguese. Also, there are some misinformation and conflicting data. Thus, in this work, based on an extensive study, the Boate Kiss fire tragedy is presented and some of the main aspects related to the incident are pointed and discussed. Nevertheless, it is important to highlight that this is a recent event and that many lawsuits are still in progress; therefore, some of the information provided here might still be subjected to modification.

The Brazilian standard ABNT NBR 9077 [19] is also briefly described, specially the section related with the dimension of the emergency exits for environments such as nightclubs.

Despite the apparent triviality, human movement can influence our quality of life and the personal security, thus it has being increasingly studied. Human movement is a sophisticated subject encompassing a number of different disciplines, including the possibility of the occurrence of emergent phenomena resulting from the interaction between agents [20-22].

The computational simulation emerges as a promising tool to be able to study both the human movement as well as their relationship with the environment where it happens, even in stressful conditions [23,24]. Some discrepancies between the results of simulations can occur depending on the methodology/model employed, even in simple

\footnotetext{
${ }^{1}$ An arson fire in a circus, that happened in 1961, whose canvas used in the cover easily propagated the flames, causing about 500 deaths [2].

${ }^{2}$ NFPA, 2013 (http://www.nfpa.org/safety-information/for-consumers/occupancies/nightclubs-assemblyoccupancies/deadliest-public-assembly-and-nightclub-fires).
} 
environments $[21,25]$. However, more and more the crowd simulation will be use to help to find solutions to many problems in several areas, such as computer graphics, animation, pedestrian dynamics, robotics, among others [26]. Specifically for Boate Kiss, some preliminary simulations of the evacuation have already been done ${ }^{3}$, but many questions are still open to debate.

Thus this work describes in detail the event aiming to provide subsidies so that more complete simulations can be carried out later, allowing a better knowledge of the subject. Additionally, with the informations about the tragedy and using some already established values about people flow, the values of traditional concepts such as ASET (Available Safe Egress Time) and RSET (Required Safe Egress Time) [28] were then estimate.

At the end, it is demonstrated that even if the requirements of the Brazilian standard were thoroughly followed, serious accidents could still potentially occur in certain situations. It could also be seen that the wording of the Brazilian standard facilitates different interpretations, which further weakens the regulations. Therefore, ABNT NBR 9077 cannot be considered appropriate for the dimensioning of emergency exits in places such as Boate Kiss.

From the evidences, one could conclude that the phenomenon that happened in Boate Kiss was so fast that even emergency exits dimensioned according to a more rigorous standards might not be enough to ensure a completely secure evacuation in that situation. Finally, some considerations are made in order to improve the fire and safety standards, specially with respect to the dimensioning of emergency exits.

\section{Background}

\subsection{Boate Kiss Tragedy}

Santa Maria is a city located in RS (Rio Grande do Sul State), in the extreme south of Brazil. It is a medium-size city (276,108 inhabitants), with a municipal HDI (Human Development Index) considered high (0.784). Also, it is eminently of urban occupation and has a large number of faculties and public institutions ${ }^{4}$. The Kiss nightclub was located in the centre of Santa Maria, in a residential and commercial area, and only about $2 \mathrm{Km}$ away from the nearest fire station.

Kiss nightclub had only one floor and rectangular format, with dimensions $23.18 \mathrm{~m}$ in the main street by $26.45 \mathrm{~m}$ in length (in the design from 2009, the total indicated area was $615 \mathrm{~m}^{2}$ [29]). Internally, Kiss nightclub had a sophisticated design, with various different sectors and some corridors, especially in the exit route (Fig. 1).

In RS a place such as Boate Kiss needs a fire prevention and protection plan approved by CBMRS (Fire Department of RS) ${ }^{5}$. However, the process to obtain a legal fire license

\footnotetext{
${ }^{3}$ For example: Bowie State University, 2016 (http://www.cs.bowiestate.edu/sharad/vrlab/nightclub.html) and [27].

${ }^{4}$ IBGE, 2016 (http://cidades.ibge.gov.br).

${ }^{5}$ Rio Grande do Sul, Law № 10.987, august 11, 1997; and Brigada Militar - Secretaria da Justiça e da Segurança - Rio Grande do Sul, Portaria № 138/EMBM/2002, november 20, 2002.
} 


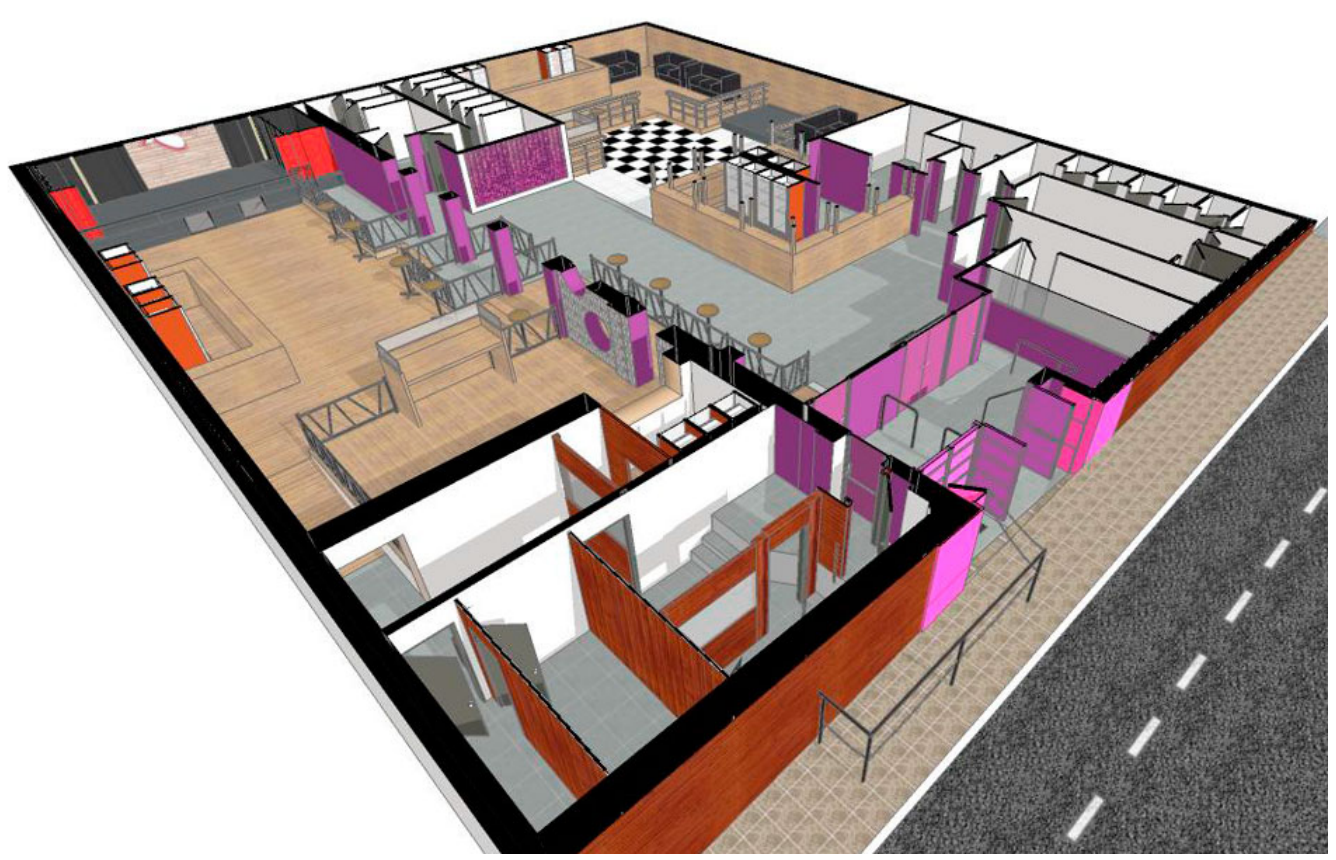

Figure 1 Schematic perspective view of Boate Kiss (image source: IGP-RS [16]).

was over simplified, and Boate Kiss could get its authorization of conformity against fire without an updated fire protection project made by an appropriated professional [14,29]. On the day of the tragedy its fire license was expired but undergoing renovation [9,29]. Rio Grande do Sul adopts, in many cities, a computerized system called SIGPI - "Sistema Integrado da Gestão da Prevenção de Incêndio"6, which in addition to the administrative concern of the fire prevention and protection plan also deals with the technical aspects.

SIGPI, theoretically, should contain the technical details and observation guidelines required by the applicable law and was considered as a great success ${ }^{7}$. However, according to [14], SIGPI "is flawed, incomplete and simplified to the point of giving primacy to the amount (superficial inspections) over quality ...". Yet, the situation is so serious that "SIGPI system facilitated the fire that occurred in the Boate Kiss and, consequently, contributed to the amount of deaths and injuries that took place" (free translation). It is noteworthy that more than 100,000 other fire prevention processes in RS were also approved using SIGPI. Due to this tragedy, the specific legislation of RS was changed ${ }^{8}$ and became a little more rigorous.

The internal noise generated by Boate Kiss caused a big problem with the neighbourhood, specifically during the nights [15]. Thus, the entire nightclub was sealed in order to avoid noise dispersion. There were absolutely no open windows or alternative ways to eliminate the fumes.

The fire started in the roof above the main stage after the ignition over the acoustic

\footnotetext{
${ }^{6}$ Integrated Management of Fire Prevention (free translation).

${ }^{7}$ França, M. and Felippetti, C.. Sistema Integrado da Gestão da Prevenção de Incêndio - SIGPI. III SEMARES, 2009. (in portuguese, slides).

${ }^{8}$ Rio Grande do Sul, Complementary Law № 14.376, december 26, 2014; among others.
} 


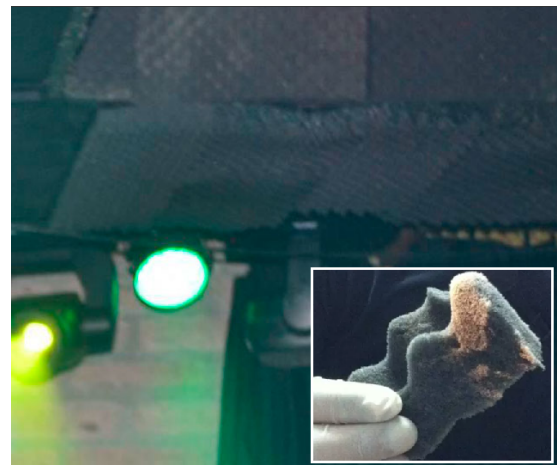

(a)

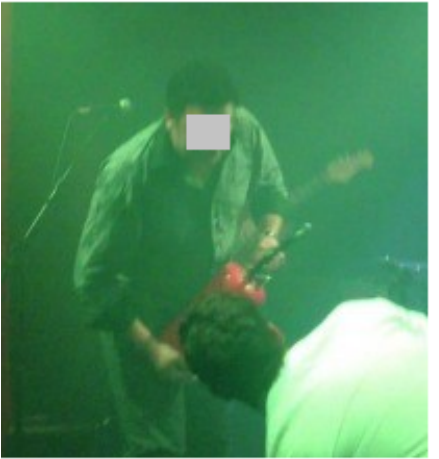

(b)

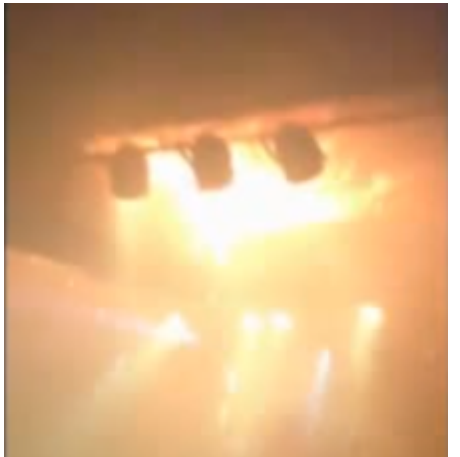

(c)

Figure 2 In (a) an image taken before the tragedy showing the acoustic foam installed and in the highlight a piece of this foam, in (b) the exact moment when a member of band takes the fire extinguisher to try unsuccessfully fight against the fire in its early stage, and in (c) the fire at around 35 - 45 $\mathrm{s}$ after its beginning. Images source: (a) adapted from IGP-RS [16], (b) and (c) adapted from a cellphone video (unknown author).

foam (Fig. 2(a)) of a cheap pyrotechnic device called "Chuva de Prata"9 [9] - prohibited for indoors use - by a member of the band that was performing in the premises. Soon after the beginning of the fire, a fire extinguisher was used in an attempt to extinguish the fire in the roof (Fig. 2(b)), but with no effect ${ }^{10}$. The Fig. 2(c) shows a image of the fire over the acoustic foam at around $35-45 \mathrm{~s}$ after its beginning ${ }^{11}$.

The fire started very near the air conditioning system. This helped to accelerate the dispersion of smoke all over the room of the main stage [9]. It was really a very fast phenomenon. There are evidences reporting that the smoke took no more than three minutes to engulf almost the entire nightclub [7]. Experimental simulations with the foam used in Boate Kiss ${ }^{12}$ shows that it took only $12 \mathrm{~s}$ for the fire to spread in a large area of foam and that, in only $90 \mathrm{~s}$, the region was fully occupied by smoke.

Furthermore, there was no kind of flame retardant in the acoustic foam nor operational smoke suppression systems installed in the nightclub. The smoke generated took a critical importance in this tragedy.

The excerpt below, a transcript of the police investigation of the tragedy [14], helps to illustrate some of the numerous problems which have occurred:

"Panic took hold of individuals who were in the club, causing people to despair and try to leave the place, but Boate Kiss had only one exit that led to the outside. That exit was absolutely insufficient to give flow to the amount of

\footnotetext{
${ }^{9}$ Silver Rain (free translation).

${ }^{10}$ According to [9], the fire extinguisher was empty (not operational) because some days before tragedy it was foolish used in a birthday celebration and repositioned in its place without being recharged.

${ }^{11}$ There is a video taken soon after the beginning of the fire from a cellphone of one of the victim. See for example: unknown author, 2013 (https://www.youtube.com/watch?v=Cn9VT830nGk).

${ }^{12}$ G1 - Jornal Nacional, 2013 (http://g1.globo.com/jornal-nacional/noticia/2013/01/simulacao-mostracomo-fogo-se-espalhou-rapidamente-por-espuma.html).
} 
people throng in desperate attempt to leave the area, many of which have died trying to. Not only due to the single exit, but the existence of several physical barriers, guard rails (containment bars) in the exit routes, stairs, emergency lighting disability, lack of indication or escape routes signalling, in addition to the crowded site, also contributed to the resulting damage, factors that together hampered the rapid evacuation of the premises" (free translation).

To exemplify one of the above points, Boate Kiss had two emergency exits to comply with the Brazilian standard [19], but these exits were placed side by side, so that in fact it had only a single double-sized emergency exit (Fig. 1). Later on, experts considered that this single exit was irregular [30], but this is a point not fully covered (or dealt with) in the applicable Brazilian standard [7,9,29]. The investigation has shown that the effective unique double exit was known to the municipal government and also to the local Fire Department. However these authorities, probably due to gaps created by the wording of the prescriptive rules [7], and the institutionalized relaxation and disregard with the inspection for fire safety [30], did not restrain this condition.

The original fire prevention and protection plan in the CBMRS of the Boate Kiss did not have data about the maximum capacity of the nightclub ${ }^{13}$. According to IGP-RS (General Institute of Forensics of RS), the nightclub had a capacity of 769 people [16]. However, the real number of people during the tragedy could be higher (until now the real occupation has not being precisely determined, but only the numbers of deaths and injured "proves" that the nightclub was overcrowded). It seems reasonable to consider the number of 1,000 persons as being one the actual total occupation at the moment of the tragedy.

Additionally, instead of keeping the project from 2009 approved by the local municipality [29], and the environment according to what was previously approved by CBMRS in 2009 and 2011 [9], the owners have changed it. Some relevant modifications were made in the finishing materials (there is no acoustic foam in original plan) and also in the internal design (iron bars in the exit route were added (Fig. 3), amongst others).

There is no official and updated design elaborated by an architect or engineer formally including these modifications approved by CBMRS [29]. The two above mentioned changes have had great impact on the tragedy: the addition of the foam where the fire started caused the consequent release of the toxic fumes and the placement of the bars that contributed to the increase of the bottleneck effect during the evacuation. The foam was used to improve the quality of sound (to avoid reverberation) and was also largely used in other nightclubs in Santa Maria ${ }^{14}$.

According to one associate of Boate Kiss in an interview ${ }^{15}$, some of these design al-

\footnotetext{
${ }^{13}$ A senior officer of CBMRS was accused of allegedly (and fraudulently) introduce into the fire prevention and protection plan after the tragedy that the maximum occupancy would be of 691 people, information widely publicized as true (http://diariodesantamaria.clicrbs.com.br/rs/geralpolicia/noticia/2015/09/bombeiro-condenado-por-fraudar-processo-da-kiss-faz-um-desabafo-em-carta4838727.html).

${ }^{14} \mathrm{ZH}, 2013$ ( http://zh.clicrbs.com.br/rs/noticias/noticia/2013/03/espuma-usada-na-boate-kiss-era-comumnas-casas-noturnas-de-santa-maria-4066933.html).

15 "Gugu Show" by TV Record, screened in Brazil on Mar 30th, 2016.
} 


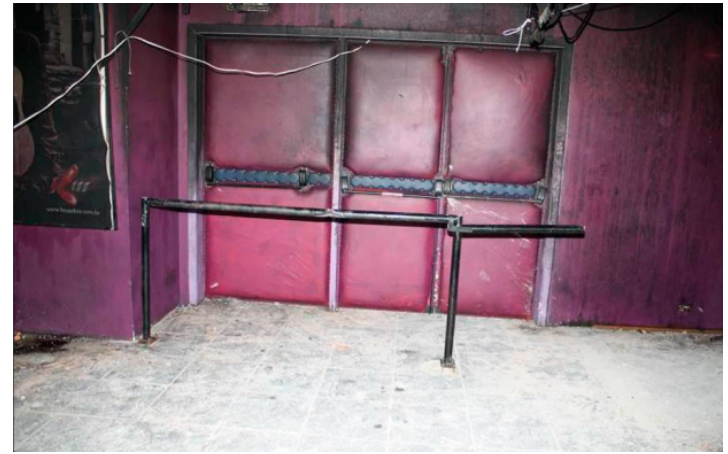

(a)

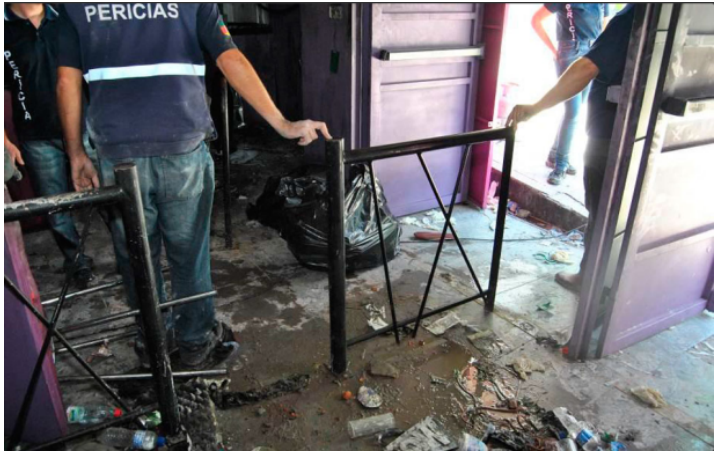

(b)

Figure 3 Images of some of the bars added by owners in the evacuation route near to exit of Boate Kiss. Additionally, in (a) the middle door was locked (images source: IGP-RS [16]).

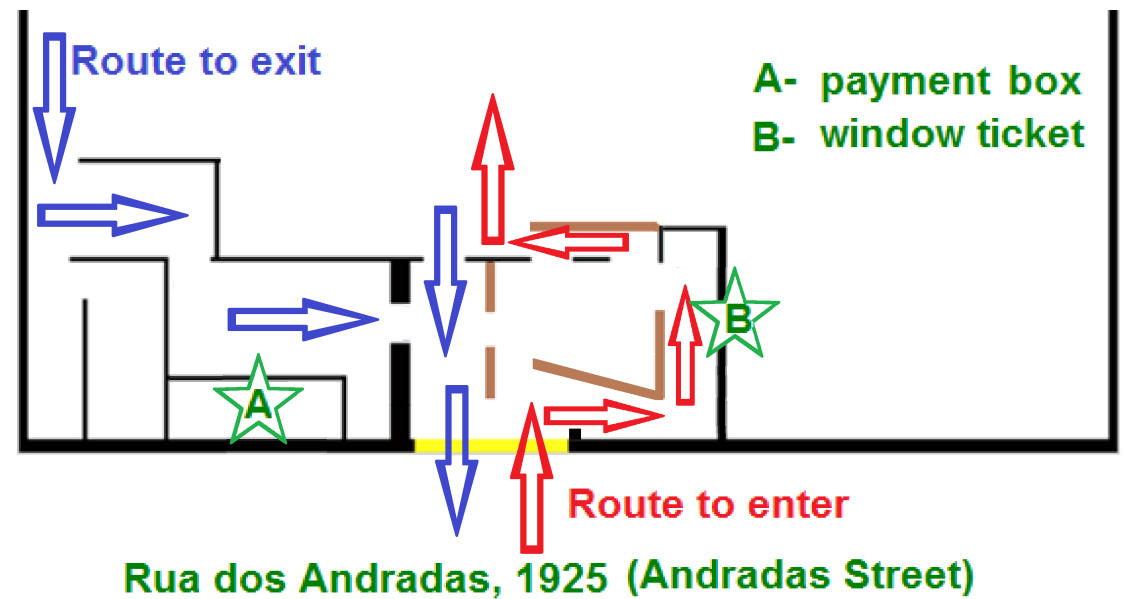

Figure 4 Stylized top view of Boate Kiss entrance area (in black the walls, in brown the bars showed in Fig. 3 , in blue the route to the way out of the nightclub and in red the route to enter the nightclub, no scale).

terations in the original exit route occurred to facilitate the entrance and exit control, to avoid unauthorized people to leave the nightclub and to facilitate the bill payment (all the food and beverage consumption within the nightclub was paid only when the costumer left the premises) and also allowed a more secure admission.

Fig. 4 helps us to understand these points, where the blue arrows show the path to be followed to exit the nightclub, and the red arrows show the path to be followed to enter the nightclub. The flow of people of this formal procedure for the control of entrance and exit resembles the operation of a "dropper".

The security staff of the nightclub ensured the correct operation of this enter/exit protocol. Unfortunately, in the first moments of the tragedy, they do not allow people to leave the location and requested them, before exiting, to make the due payment of the bills. However, when they finally realized what was happening the output path was released.

There were no fast communications about the fire among staff inside the nightclub 
when it began. Many occupants, mainly those who were not in the main stage area, including the staff, only were aware about the in-course tragedy when they saw the smoke. There was no fire alarm and the emergency lights were not activated because the electric supply was not interrupted.

An important point that also happened before in other fire tragedies is that, several people, after leaving the nightclub and without any kind of appropriate equipment, reentered the room. Most of them acting with a helping behaviour [31] were looking for friends or just trying to rescue and save lives, but unfortunately at least five of these heroes died during these attempts. However, there exists at least one report of one person re-entering the nightclub for a trivial reason (to pick up an music instrument left behind) and that ended up losing his life [9].

The fire fighters arrived very fast in the nightclub [9]. Nonetheless, they were not really prepared for what they found there [14]. In this short time between the start of the fire and the arrival of the fire fighters (around eight to ten minutes), it is estimated that most of the deaths were already consummated (the toxic and asphyxiating gases were fatal and very fast) ${ }^{16}$.

The Fig. 5 shows a stylized top view plant of Boate Kiss. To better visualise the entire environment and the tragedy, Fig. 5 identifies several view points covering the most part of Boate Kiss (letters a to q). Only Fig. 5(a) was taken before the tragedy. Most of these images in Fig. 5 speak for themselves, but here some details are highlighted.

Fig. 5(a) shows a huge line of people in the outside waiting to enter in the nightclub (it was a very popular space). Fig. 5(b) show same intermediaries doors of Fig. 3(a) seen from the outside. And, finally a positive point: the individual left door in the image that was added by the owners (this door was not in the original project) but unfortunately it was incapable to compensate or to prevent the congestion caused by the bars.

Fig. 5(c) shows various young civilian men who evacuated the nightclub but remained at the scene which, with only some manual equipments, tried to break the external wall and to create an alternative passage ${ }^{17}$. They took turns in this volunteer action. Unfortunately, they were not fast enough to save anyone with this procedure. One of these men said $^{18}$ :

"Every hole that we could do, freed a lot of smoke, but there was a lot of soot. I felt a dry mouth, my eyes hurt, headache. When we managed to open one of the holes, the fire fighter began to pull people and check the pulse. However, they were already dead" (free translation).

Fig. 5(d) shows again the intermediary doors from inside the nightclub, but without the bars showed in Fig. 3(a), because the bars - although firmly fastened to the floor - were torn by the crowd in despair, showing the degree of congestion caused by them (the bars

\footnotetext{
${ }^{16}$ The fire began around 3:15AM, and the fire fighters already were there at about 3:23AM (http://veja.abril.com.br/brasil/eles-sobreviveram-ao-inferno-da-boate-kiss/).

${ }^{17}$ According [9] these action had been started by the fire fighters.

${ }^{18}$ Folha de São Paulo, 2013 ( http://www1.folha.uol.com.br/cotidiano/2013/01/1223289-jovens-quequebraram-paredes-da-kiss-relatam-como-enfrentaram-a-fumaca-toxica.shtml).
} 

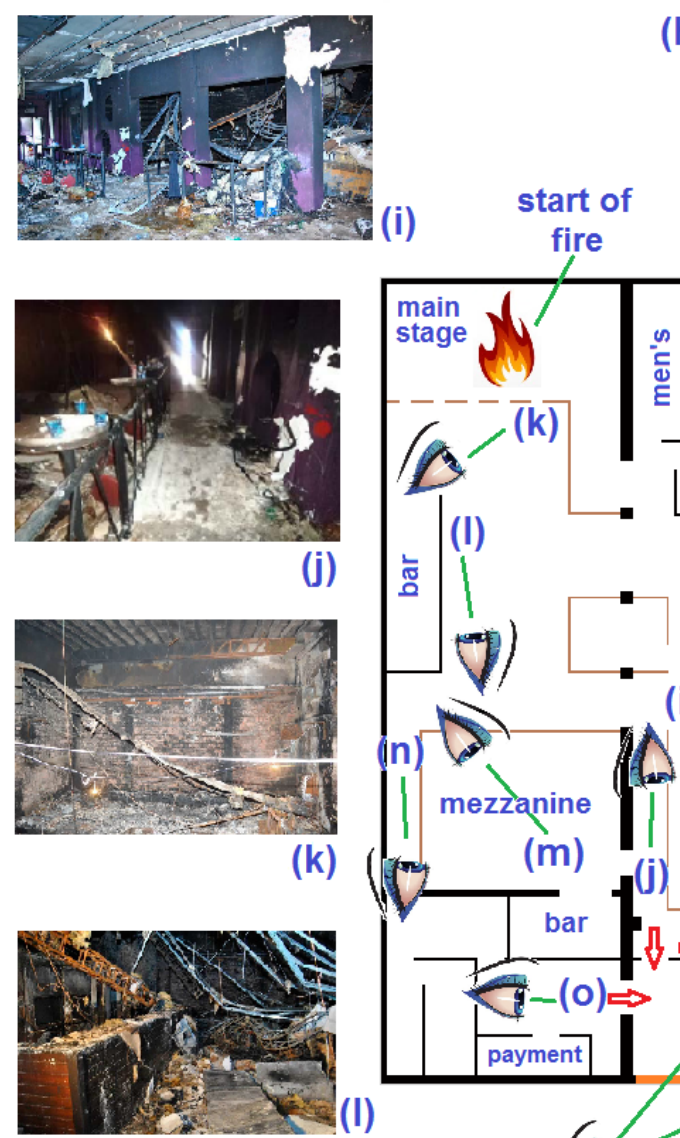

(h)
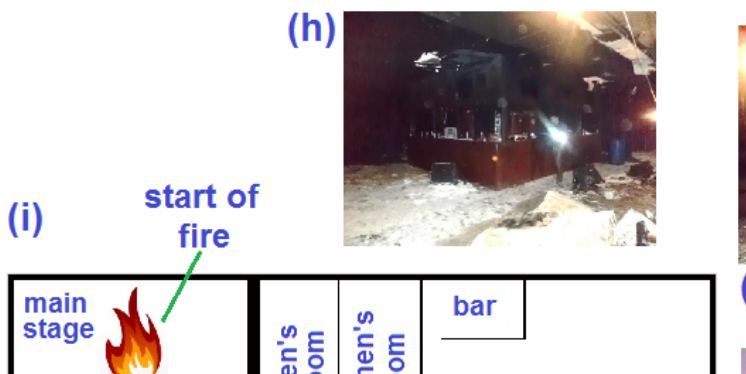

(g)
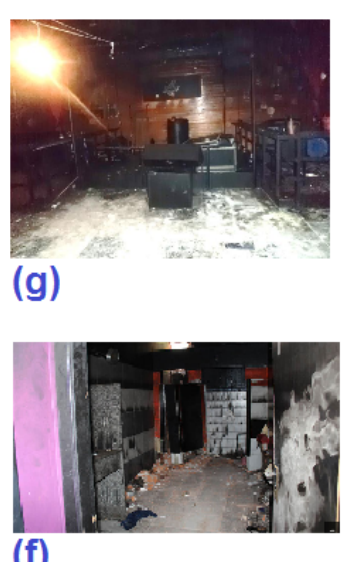

(f)

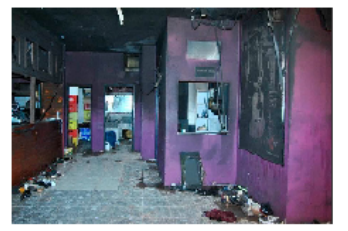

(e)

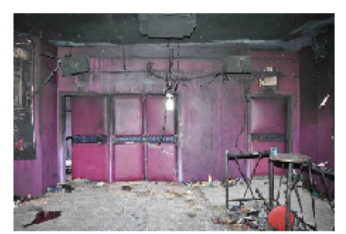

(d)

(c)
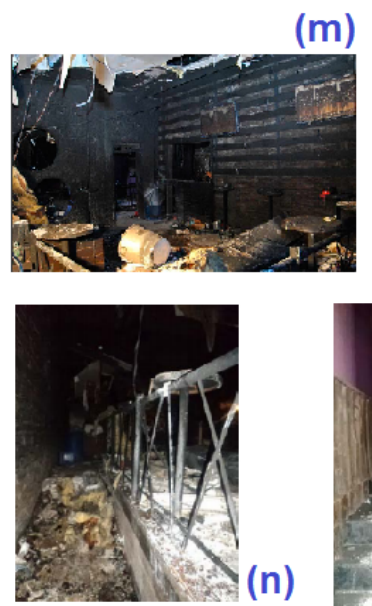

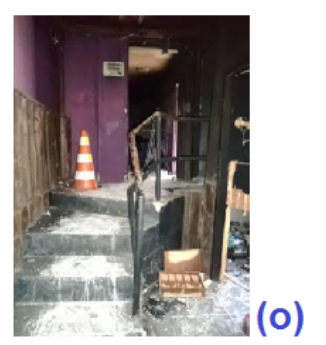

(a)
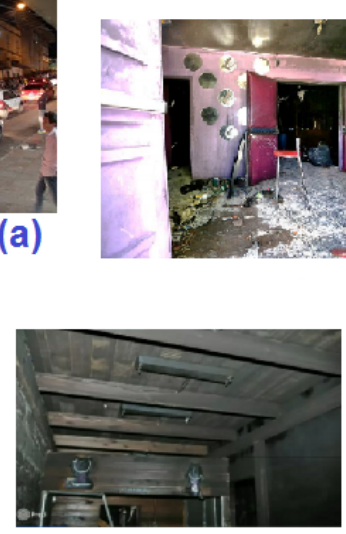

(p)

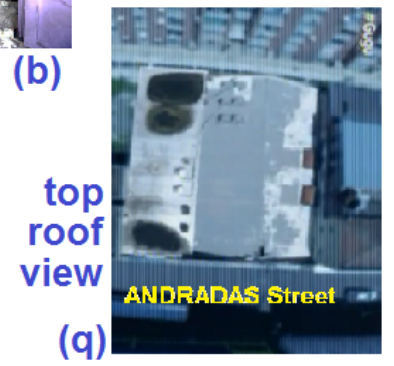

Figure 5 Stylized top view plant of Boate Kiss (no scale). Around images source: (a) from ; (b), (d), (e), (f), (g), (h), (i), (j), (l), (m) and (p) from IGP-RS; (c) from "Globo News"; (k), (n) and (o) from CREA-RS [29]; and (q) adapted from "Gugu Show" in TV Record. 
were put back afterwards by the investigators). Unfortunately the middle part of the triple door indicate in Fig. 5(d) (or Fig. 3(a)) was locked [16].

Fig. 5(e) shows the path followed by many people that, even practically facing the exit, got confused, blocked (or were driven), and went to the bathrooms. This happened mainly because some survivors said that in the darkness of the smoke, there was a visible light in bathrooms direction. About 180 bodies were founded in bathrooms and around it ${ }^{19}$. Fig. 5(f) shows an image of men's bathroom, where a expressive quantities of bodies has been removed [9] (there was no window even in bathroom). Fig. 5(g) shows the second stage, where is possible to visualise that the fire did not reach the area (because this fire was oxygen poor, the flashover did not happen [7]).

Fig. 5(h-i-j) show different angles of the intermediary saloon. Fig. 5(k) shows the main stage, where the fire began (everything there was destroyed), Fig. 5(l) shows the bar by the side of the main stage, and Fig. 5(m) shows the inside of the mezzanine. Fig. 5(n) shows part of the route to the exit located by the side of the mezzanine, and Fig. 5(o) shows the exit door, immediately after the payment box. Fig. 5(p) shows the inside of the other small mezzanine just above the payment box, where the ceiling was completely impregnated with soot.

Fig. 5(q) shows an aero view of the nightclub, where three black stains can be seen. The two black stains side-by-side are the primary and secondary sources of the fire and the third black stain, near Andradas Street, is the point where the hot gases concentrated (the hot gases follow the exit route to the mezzanine above the payment box, in the upper part, because there were no alternative paths [9]).

Finally, in Fig. 5 there are three red arrows in the region of the exit. Those arrows indicate the most critical passage points to the exit of the nightclub. Hence, these are the elements that, associated with the routes to reach them, really control (or limit), at the first moment of the evacuation, the flow and, consequently, the time of escape.

\subsection{Brazilian Standard}

ABNT - Associação Brasileira de Normas Técnicas, is the Brazilian Forum for standardization, recognized by the national society since its founding in 1940, and confirmed by the Brazilian Federal Government through various legal instruments [32]. The standard to determine the quantity and the dimensions of the emergency exits in buildings is ABNT NBR 9077 [19]. It is important to state that, in reality, as a substitute of the national standard, each Brazilian state can have its own legislation, but in general they are very similar and comply with ABNT. Hence, the relevance to discuss and improve the standard.

The first Brazilian national standard to regulate dimensions of emergency exits in building was published in $1974^{20}$ (NB-208: Exit emergency in High Buildings) [35]. One can say that NB-208 was a collateral effect of several fire tragedies that happened in the earlier 1970's as in Edifício Andraus (São Paulo, 1972, with 32 deaths), Lojas Americanas

\footnotetext{
${ }^{19}$ G1 Globo, 2013 (http://g1.globo.com/rs/rio-grande-do-sul/noticia/2013/01/capitao-diz-ter-tirado-maisde-180-corpos-de-banheiro-de-boate-no-rs.html).

${ }^{20}$ This Brazilian national standard is very recent when compared to countries like the US, whose standards already existed more than half a century before $[33,34]$.
} 
(Porto Alegre, 1973, with 5 deaths), and mainly in Edifício Joelma (São Paulo, 1974, with 179 deaths), all of them high buildings.

In 1985, it was revised to the actual designation (NBR 9077) and spread its application beyond high buildings. In 1993, it was again modified, with some improvements (although limited) such as in spaces for public meeting and in windowless buildings, and also some simplifications in the requirements for lower buildings. Finally, in 2001, a last revision was made, but with minimum modifications (just small amendments).

It is important to mention that in ABNT, NBR 9077 is not treated within the CB-24 (Brazilian Fire Safety Committee), an exclusive commission for fire safety recommendations, but by the CB-02 (Brazilian Civil Construction Committee). The standard is comprehensive but in the current paper the most relevant points applicable for the Boate Kiss episode will be addressed.

The ABNT NBR 9077 had formally as aims:

“... establishes the required conditions that buildings must possess: a) so that the population can abandon them, in the case of a fire, completely protected and with their physical integrity; b) to allow easy access to external assistance (fire brigade) to fight the fire and the withdrawal of the population" (free translation).

And it brings the following definition for an emergency exits, exit routes or exits:

"continuous paths, properly protected, provided by doors, corridors, halls, external walkways, balconies, hallways, stairs, ramps or other exit devices or combinations thereof, to be followed by the user, in case of a fire anywhere in the building until the public highway or open space, protected from the fire and with access to the street" (free translation).

Thus, the emergency exit includes, on top of the obvious doors, items such as access or horizontal exit routes, stairs or ramps and exits themselves (all those items are individually defined in the standard).

The buildings are classified according to the occupation, height, dimensions and constructive features (as in Tables 1, 2, 3 and 4 of ABNT NBR 9077 Appendix).

The minimum width of the emergency exits is given by the following equations, calculated separately for entrances and exits, stairs and ramps, and doors:

$$
\begin{gathered}
N=P / C \\
W=0.55 \times N
\end{gathered}
$$

where

$N=$ number of passages unit $(P U)$, rounded to the higher natural number;

$P=$ occupation (according to the specific criteria);

$C$ = capacity of $P U$ (referential number of people to get through the doorway in one minute); and 
$W=$ minimum width of emergency exits [m].

The value of $P$ and $C$ are functions of the building classification according to its occupation, and, additionally, the value of $C$ is different for entrance and exit, stairs and ramps, or doors. One $P U$ is given by $0.55 \mathrm{~m}$. The minimum width never can be less than $1.10 \mathrm{~m}$ (or $2 P U$ ), except where stated.

According to the occupation, Boate Kiss is classified as F-6 group. Therefore, for example, considering a building classified as F-6 group and with an useful floor area for occupancy of $385 \mathrm{~m}^{2}$ (areas such as bathrooms or staircases are not considered as useful areas), the admitted population will be of 770 people ( 2 person by square meter). In this case, $C$ is equal to 100 for accesses and doors and, according to Eq. 1 and Eq. 2, the minimum width of all emergency exits (accesses and doors) must be equal to $8 P U$ (or $4.40 \mathrm{~m})$.

This standard imposes the necessity of a minimum of two different emergency exits for Boate Kiss. However, there is no compulsory specification about the best positioning for the exits; hence, in theory, the exits can be placed anywhere.

The standard also determines the maximum distance to be covered by a person up to the exit of the building or to a refuge area. This maximum distance depends on some parameters such the number of exits, if there is a sprinkler system and on the classification of the building according to the constructive features about resistance and fire propagation. For example, for buildings without a sprinkler system, classified as type $\mathrm{X}$ (easy fire propagation), the maximum distance should be $20 \mathrm{~m}$. But, if it was classified as type $\mathrm{Y}$ (medium resistance to fire), the maximum distance would be $30 \mathrm{~m}$.

According to ABNT NBR 9077, Section 5.2.2c, a windowless building (such as Boate Kiss), with an occupation higher than 100 persons and many finishing of inflammable material, should have an automatic smoke suppression system and sprinklers. However, unfortunately Section 5.2.1.4 is not clear regarding the application of this regulation to a building such as Boate Kiss; therefore, in practice it is not applicable.

Additionally, despite not being directly treated in this standard, for buildings classified as short and with a small internal area $\left(\leq 750 \mathrm{~m}^{2}\right)$, exactly as Boate Kiss, many other regulations in RS are not considered clearly mandatory, i.e., the need of a hydraulic system (hydrants or sprinklers) or a smoke suppression system.

\section{Discussions}

Using the concept of $C$ and another specific criteria from ABNT 9077 before presented, the total escape time might be estimated by:

$$
t_{\text {escape }}=k \times \frac{P_{\text {real }}}{L}
$$

where

$t_{\text {escape }}=$ total escape time $[\mathrm{s}]$;

$k=0.33$ [m.s/person]; 
$P_{\text {real }}=$ real population of environment [person]; and

$L=$ total width of emergency exits [m].

The results show, obviously, that the smaller the exit width, or the bigger the population, the higher would be the escape time.

Considering an exit width of $4.40 \mathrm{~m}$ (according to IGP-RS [16], this must be the minimal width exit from their interpretation of ABNT 9077), the $t_{\text {escape }}$ will be of approximately $56.3 \mathrm{~s}$ for a 750 persons occupancy. If the reaction and the perception times are not taken into account, and for a no stressful evacuation, this is a reasonable time.

However, keeping constant this population of 750 persons, and considering an exit width of approximately $3.60 \mathrm{~m}$, the time for evacuation of the whole environment would have been aprroximately $68.8 \mathrm{~s}$. Considering only the size of the actual doors, the total exit width would be $3.20 \mathrm{~m}$ [29], and the escape time would raise for approximately 77.3 s. But, considering yet all restriction, the total exit width would only be $2.50 \mathrm{~m}^{21}$ and the time for escape would be of $99 \mathrm{~s}$.

But what was the real effective exit size of Boate Kiss? Observing the plant of Fig. 4, the three red arrows indicate that there are exactly three restriction passages. The first passage is located after the payment box, another by the single door that separate the intermediate saloon between the entrance and the inside of the nightclub, and the third passage is located on the side of the bar, added near the triple door. Each one of these passages, or route to them, have more than one $P U$, but less than two $P U$. Thus, in reality each one can be only considered as one $P U$, or $55 \mathrm{~cm}$, what implied that Boate Kiss exit had truly only $1.65 \mathrm{~m}$ of effective exit (three $P U$ ).

Considering this $1.65 \mathrm{~m}$ of exit, the total escape time would be $150 \mathrm{~s}$, and considering a higher, but possible realistic population of 1,000 persons, the $t_{\text {escape }}$ will go to $200 \mathrm{~s}$. However, in fact, this could also be worse because, considering the nightclub layout, the passage after the payment box was certainly sub-used; but this type of situation would not be considered ${ }^{22}$.

Now, add to this total escape time of $200 \mathrm{~s}$ the times for reaction and perception, the very quick advance of hot and toxic smoke into the nightclub, no general visibility, the establishment of non-adaptive behaviour ${ }^{23}$, the exchange of energy between persons in escape (pushed and trampled people), no visible indication of exit in the darkness, the security staff blocking the exits door in the beginning of the fire, the effect of the inner design and a confused layout blocked by bars in a crowded environment. That was what happened in Boate Kiss that night.

As already shown for other environment [37], the time for escape available according to standards can be considered satisfactory only if all conditions in escape or in the environment are favourable. But in a situation of emergency in real places, as it happened in

\footnotetext{
${ }^{21}$ Investigators considered the effective total width exit of Boate Kiss as only approximately $2.50 \mathrm{~m}$ due to the influence of "leaves" and restrictions of the doors and obstacles [16].

${ }^{22}$ If the passage after the payment box was not considered as valid, the total effective exit width will be only $1.10 \mathrm{~m}$.

23،... refer to the destructive actions that a crowd may experience during a disaster, such as stampede, pushing others out of the way, knocking others down, and trampling on others." [36].
} 
Boate Kiss, this can be far from the truth.

From the already presented one can consider that maximum ASET is only about 90 s. However, the hand calculations indicate that minimum RSET would be something around $200 \mathrm{~s}$, considering a population of 1000 persons, an adaptive behaviour, the ever selection of the shortest route until the exit, and a exit of $1.65 \mathrm{~m}$ (in true, considering the non-adaptive behaviour and the influence of the non-visibility in the route choice [38] the RSET will be higher). Thus, became clear that the maximum available time is really much shorter than the minimum required time (ASET $<<R S E T)$.

Additionally, this hand calculation method not consider the effect of the population distribution or any type of obstruction, among another simplifications, which results in underestimated values for the $t_{\text {escape }}$. Thus, it has also become very clear that, for safety, in addition to the use of all available resources to avoid fire, or its propagation and consequences, an alternative is to adopt in environments such as nightclub an evacuation route with larger width, over the standards specification, even for the most rigorous.

Similar reflection can be made for the phased evacuation of tall buildings, widely used in several countries [33]. This technique presents very promising results, but there is no guarantee and their effective application can be very difficult to be attained in real situations [39].

Back to the Brazilian standard, the use of ABNT 9077 for an environment with size and occupation similar to Boate Kiss allows several interpretation possibilities, even with the reduction of the imposing requirements. Unfortunately, when the interpretation is not very clear, the less expensive option is usually the preferred one.

For example, ABNT 9077 in its Section 3.48 gives a definition for the emergency exit set, considering as components the emergency exit, the exit route or the exits, but there is no mention to the term "set". Maybe, that is why throughout the ABNT 9077, the emergency exit term is used to describe the combination of the entire exit "set". Unfortunately, this is a point that causes confusion. No rarely, the user of the standard considers as the emergency exit set only the exit door itself, neglecting all other items such as the access route. This is noticeably very dangerous because there is no reason for the use of a large door with a narrow route to reach it, or the existence of two separate doors but linked by the same narrow route. The solution is very simple, just rewrite the standard clearly specifying, at each citation of emergency exit term, what is actually been dealing with, and use the term "set" or similar in the definition, even in the title of the standard.

The lack of specification of the distance between the exits is another big problem in ABNT 9077. Keeping the emergency exits far and independent from each other will make the building safer. In case of a fire blocking one of the exit route (as happened in the Rhythm Club Natchez fire at the only exit available [3]), there will be at least another route option for evacuation. Yet another vantage is the reduction of the average distance to the nearest exit [40]. For example, the NFPA 101: Life Safety Code ${ }^{24}$ in its Section 7.5.1.3.2 establishes that the separation distance between two exits must not be less than half the length of the maximum diagonal of the area served by these two exits [7].

Additionally, the ABNT 9077 brings no information about the minimum individual

\footnotetext{
${ }^{24}$ NFPA - National Fire Protection Association, USA (http://www.nfpa.org).
} 
capacity of each exit. This might cause dangerous situations, because in case of an evacuation the population can concentrate in some specific exit, leaving the other exits under used [41,42]. To avoid or minimize this effect, for example, the NFPA 101 and NFPA 5000: Building Construction and Safety Code sets that the main entrance/exit of a building type nightclub require the exit capacity of not less than two-thirds of the total occupancy. Yet, according to NFPA, the other exits require the evacuation capacity of not less than one-half the total occupancy [3].

Because of problems like these (some very basic), the local fire codes in Brazil are usually made based on ABNT 9077 but with its particularities. For example, the CBPMESP (Fire Police Department of the State of São Paulo, Brazil) published its own standard based on the ABNT 9077, but using a more clear interpretation, the technical instruction IT $11^{25}$, that is complemented by others local codes. Most of the sections are more rigorous, although far from the ideal. IT 11 determines recommendations specifically for environments of the group F-6, such as nightclubs. This is very important because this group have its own characteristics.

After the tragedy in The Station nightclub, in 2003, the NFPA was revised and the use of an automatic sprinkler system in environments like that of Boate Kiss became mandatory [3] (in ABNT 9077 there is nothing about this). In general, there is no doubt about the great relevance of this measure, specially for avoid the occurrence of flashover (what did not happen at Boate Kiss). However, unfortunately, the speed of the spreading of the toxic smoke was so intense that it can not be said that this measure alone would be able to avoid the whole tragedy ${ }^{26}$.

There are various possible types of bottleneck effects [43]. In Boate Kiss two bottlenecks had great importance, one of them in the bars added at the exit route (Fig. 3(a)). The amount of people wanting to leave was so big that these bars were torn down. The other one was in bathrooms next to the exit area, where the bidirectional flow of people wanting to go towards the restrooms and wanting to get out prevented the movement [9].

There is another very important point (almost never discussed), the formation and training of the professional responsible for the elaboration of the fire protection projects. In Brazil there is not a formal professional like a Fire Protection Engineer, or similar. Some other engineers, such as Civil Engineer, Electrical Engineer, Occupational Safety Engineer, or even Architects, immediately after graduation have the legal competence to elaborate all level of projects against fire. However, there is no formal capabilities evaluation. Also, this topic is not properly treated in the universities. This is a huge problem, which is already being pointed out [44-46], but with no prospect of change in a foreseeable future. The culture of safety against fire is not yet on the Brazilians horizon, even by specialists. This is an additional side that stresses the need for more rigorous and clear standards.

To finish, despite this tragedy in many ways can be considered a repetition of previous events, much can be learned from it. It is expected that this knowledge must be more fully discussed, before another similar tragedy happen ${ }^{27}$. However, many questions are

\footnotetext{
${ }^{25}$ CBPMESP: IT 11/2014 - Emergency Exits. Corpo de Bombeiros da Polícia Militar do Estado de São Paulo, 2015. [in portuguese].

${ }^{26}$ Negrisolo, W.: Revista Incêndio, v. 15, n. 117, April, 2015, pp. 44. [in portuguese]

${ }^{27}$ The last great fire tragedy in a nightclub with a lot of similarities to Boate Kiss happened in Romania,
} 
still not addressed. To illustrate, the following points can be raised: what would be the real contribution of the air conditioning system in the scattering of the smoke; environmental variables and others can significantly influence the route-choices [47-49], then what are the influence of each one the collective and environmental factors that caused people to move toward the bathroom instead of the exit; how realistic can one deal with accessibility and disability's issues for an evacuations in non-adaptive behaviour situation associated to a high population densities in a nightclub?

\section{Final Considerations}

Considering that the eventual need of an evacuation in situations where a non-adaptive behaviour is installed, as in the Boate Kiss tragedy, the Brazilian standard ABNT NBR 9077:2001 should simply not be taken for emergency exits sizing purposes in buildings such as nightclubs or similar (public meeting in closed places). Additionally, it is recommended that all buildings, of the nightclub or similar type, whose emergency exit project has already been prepared and approved based only on this standard should be revised. In Rio Grande do Sul State the situation was yet worse because they over simplified the whole process of getting a fire license.

However, an important point to be highlighted is that even using a slight safer standard for the dimensioning of the emergency exits, the prevention of life lost in situations such as the Boate Kiss fire is paramount.

The reason is because literally there are almost no time for escape in a situation with high population density in a confined space full of toxic smoke. In this situation, everyone will try to leave immediately and there is no alternative option to be considered. Thus, it is necessary to adopt different mechanism to really avoid the fire or its propagation, and consequently the smoke, using, beyond the fire extinguisher and signalization, resources such as sprinklers, hydrants, automatic smoke suppression , fire brigade, efficient alarm and lightning, population and layout control, material finishing control, a well elaborated project against fire, and all connect in an efficient safety management procedure. Additionally, considering the social risks involved, an independent and serious inspection is required. The keyword is redundancy, in order to make the environment more resilient to an eventual sinister.

However, all these apparatus are expensive, and small or medium size enterprises usually not have interest, or even condition, to make this kind of investment. Unfortunately, these closed environments, even the smallest, when used for public meeting can be potentially dangerous, thus the authorities cannot simplify the fire and safety specifications. Another extra possibility is to adopt several large doors, with wide independent exits routes, even above the specifications recommended by standards.

Acknowledgements The authors would like to thank CAPES and FAPEMIG for their financial and material support during the course of this work.

2015 (http://nfpatoday.blog.nfpa.org/2015/11/romanian-nightclub-tragedy-all-too-familiar.html). 


\section{References}

[1] Albuquerque, I.M., Trevisan, M.E., Pasqualoto, A.S., Prado, A.L.C., Pereira, M.B., Badaró, A.F.V.: Physical therapy performance in the rehabilitation of survivors of the Kiss nightclub tragedy: an experience report. Fisioterapia em Movimento 28(4), 649-655 (2015). doi:10.1590/0103-5150.028.004.A001

[2] Knauss, P.A.: The city as feeling: history and memory of an event in contemporary society: the fire at the Gran Circus Norte-Americano in Niterói. [in portuguese]. Revista Brasileira de História 27(53), 25-54 (2007). doi:10.1590/S0102-01882007000100003

[3] Duval, R.F.: NFPA Case Study: nightclub fires. NFPA (2006)

[4] Strick, J.: Development of Safety Measures for Nightclubs. Lund University (2014). URL http://lup.lub.lu.se/luur/download? func= downloadFile\&recordoId=4522713\&fileOId=4522718

[5] Grosshandler, W., Bryner, N., Madrzykowski, D., Kuntz, K.: Report of the Technical Investigation of The Station Nightclub Fire. NIST (2005). URL http://www . nist.gov/customcf/get_pdf.cfm?pub_id=100988

[6] Galea, E.R., Wang, Z., Veeraswamy, A., Jia, F., Lawrence, P.J., Ewer, J.: Coupled fire/evacuation analysis of The Station Nightclub fire. Fire Safety Science 9, 465476 (2008). doi:10.3801/IAFS.FSS.9-465

[7] Moncada, J.A.: The kiss of death. [in portuguese]. NFPA Journal Latinoamericano 15(2), 18-24 (2013). URL http://www.nfpajla.org/pt/arquivos/ lugares-de-reunioes-publicas-discotecas/993-el-beso-dela-muerte

[8] Atiyed, B.: Brazilian Kiss nightclub disaster. Annals of Burns and Fire Disasters 26(1), 3-4 (2013). URL http://www.ncbi.nlm.nih.gov/pmc/ articles/PMC 3741004 /pdf/Ann-Burns-and-Fire-Disasters$26-3 \cdot p d f$

[9] Marques, G.F.: The Kiss tragedy. [in portuguese], (video). In: Seminário de Segurança Contra Incêndio e Pânico. CBMMG (2014)

[10] Sanchonete, C.R.S., Garcia, A.D.: Police comissioner Marcelo Arigony's profile on Facebook: the circulation of meanings on the fire at nightclub Kiss, in Santa Maria (RS). [in portuguese]. Dispositiva 2(2), 103-118 (2014). URL http: / / periodicos.pucminas.br/index.php/dispositiva/ article/view/7629 
[11] Souza, D.V., Machado, R.F., Montes, R.G.E., Souza, I.C.: Fire at the Boate Kiss: analysis of the ethical conduct of civil engineers [in portuguese]. Revista JurisFIB 6, 441-449 (2013). URL http: / /www.revistajurisfib.com.br/ artigos/1395811460.pdf

[12] Antonio, A.C.P., Castro, P.S., Freire, L.O.: Smoke inhalation injury during enclosedspace fires: an update. Jornal Brasileiro de Pneumologia 39(3), 373-381 (2013). doi:10.1590/S1806-37132013000300016

[13] Bassi, E., Miranda, L.C., Tierno, F.G.M.M., Ferreira, C.B., Cadamouro, F.M., Damasceno, M.C.T., Malbouisson, L.M.S.: Assistance of inhalation injury caused by fire in confined spaces: what we learned from the tragedy at Santa Maria. Revista Brasileira de Terapia Intensiva 26(4), 421-429 (2014). doi:10.5935/0103-507X.20140065

[14] Arigony, M.M., Meinerz, S.L., Vianna, M.R., Zanella, G.G., Souza, L.: Final Report Police Investigation № 94/2013/150501. Santa Maria: First Police Department of Santa Maria - RS. [in portuguese] (2013)

[15] Meinerz, S.L., Souza, L.S.: Police Inquiry Report № 001/2013. 3a DPR - RS. [in portuguese] (2014)

[16] Luiz, M.: Two years later, see 24 mistakes that contributed to the Kiss tragedy [in portuguese]. G1 RS (2015). URL http://g1.globo.com/rs/riogrande-do-sul/noticia/2015/01/dois-anos-depois-veja-24erros-que-contribuiram-para-tragedia-na-kiss.html

[17] Santucci, J.: Fire at Boate Kiss: a preventable tragedy? [in portuguese]. Conselho em Revista 9(95), 23-27 (2013)

[18] Gragnani, A., Oliveira, A.F., Boro, D., Pham, T., Ferreira, L.M.: Response and legislative changes after the Kiss nightclub tragedy in Santa Maria/RS/Brazil: Learning from a large-scale burn disaster. Burns 43(2), 343-349 (2016). doi:10.1016/i.burns.2016.08.010

[19] ABNT: ABNT NBR 9077:2001 - Buildings - Emergency Exits - Procedure. Associação Brasileira de Normas Técnicas. [in portuguese] (2001)

[20] Goldstone, R., Roberts, M.E.: Self-organized trail systems in groups of human. Complexity 11(8), 43-50 (2006). doi: 10.1002/cplx.20135

[21] Schadschneider, A., Klingsch, W., Klüpfel, H., Kretz, T., Rogsch, C., Seyfried, A.: Evacuation dynamics: Empirical results, modeling and applications. In: Encyclopedia of Complexity and Systems Science, pp. 3142-3176 (2009). doi:10.1007/978-0-387-30440-3_187 
[22] Helbing, D., Johansson, A.: Pedestrian, crowd and evacuation dynamics. In: Encyclopedia of Complexity and Systems Science, pp. 6476-6495 (2009). doi:10.1007/978-1-4419-7695-6_37

[23] Pelechano, N., Allbeck, J., Badler, N.: Virtual Crowds: methods, simulation, and control. Morgan \& Claypool (2008). doi:10.2200/S00123ED1V01Y200808CGR008

[24] Bakar, J.A.A., Mat, R.C., Aziz, A.A., Jasri, N.A.N., Yusof, M.F.: Designing agentbased modeling in dynamic crowd simulation for stressful environment. Journal of Telecommunication, Electronic and Computer Engineering 8(10), 151-156 (2016)

[25] Rogsch, C., Klingsch, W., Seyfried, A., Weigel, H.: Prediction accuracy of evacuation times for high-rise buildings and simple geometries by using different software-tools. In: Traffic and Granular Flow 2007, pp. 395-400. Springer (2009). doi:10.1007/978-3-540-77074-9_42

[26] Curtis, S., Best, A., Manocha, D.: Menge: a modular framework for simulating crowd movement. Collective Dynamics 1(A1), 1-49 (2016). doi:10.17815/CD.2016.1

[27] Silva, V.M., Scholl, M.V., Corrêa, B.A., Adamatti, D.F., Gomes, S.C.P.: Evacuation of the Kiss nightclub: a multiagent simulation of the real scenario in relation to the ideal [in portuguese]. In: $14^{\circ}$ Conferência Ibero Americana WWW/Internet, p. 5 (2016)

[28] Kinateder, M.T., Kuligowski, E.D., Reneke, P.A., Peacock, R.D.: Risk perception in fire evacuation behavior revisited: definitions, related concepts, and empirical evidence. Fire Science Reviews 4(1), 1-26 (2015). doi:10.1186/s40038-014-0005-z

[29] Silva, L.C.P., Wengrover, C., Saldanha, M., Brentano, T., Rodrigues, E.E.C.: Analysis of the sinister at Boate Kiss in Santa Maria, RS. CREA-RS. [in portuguese] (2013)

[30] Trevisan, M., Jesus, I.J.: Civil action for conviction for acts of administrative impropriety. Santa Maria: Prosecutors of Justice of Santa Maria. [in portuguese] (2013)

[31] Seivers, I., Templaton, A., Köster, G., Drury, J., Philippides, A.: Humans do not always act selfishly: social identity and helping in emergency evacuation simulation. Transportation Research Procedia 2, 585-593 (2014). doi:10.1016/j.trpro.2014.09.099

[32] ABNT: Brazilian Standardization History. Associação Brasileira de Normas Técnicas. [in portuguese] (2011). URL http://www.abnt.org.br/ images/pdf/historia-abnt.pdf 
[33] Bukowski, R.W.: Emergency Egress from Buildings. Part 1: History and Current Regulations for Egress System Design. NIST Technical Note 1623. NIST (2009). URL http://fire.nist.gov/bfrlpubs/fire09/PDF/f09017.pdf

[34] Gill, A.A., Negrisolo, W., Oliveira, S.A.: Learning from the big fires. In: The Safety Against Fire in Brazil. [in portuguese], pp. 19-33. Projeto Editora (2008). doi:10.13140/2.1.1133.5680

[35] Faillace, R.R.: Stairs and Emergency Exits. [in portuguese]. Sagra (1991)

[36] Pan, X., Han, C.S., Dauber, K., Law, K.H.: A multi-agent based framework for the simulation of human and social behaviors during emergency evacuations. AI \& Society 22(2), 113-132 (2007). doi:10.1007/s00146-007-0126-1

[37] Braga, H.C., Moita, G.F.: Modeling with fuzzy logic the dynamic of people flow during the evacuation of constructed environments dimensioned according to the brazilian legislation. In: 11th World Congress on Computational Mechanics WCCM, pp. 6458-6467 (2014)

[38] Cirillo, E.N.M., Muntean, A.: Dynamics of pedestrian in regions with no visibility - a lattice model without exclusion. Physica A: Statistical Mechanics and its Application 392(17), 3578-3588 (2013). doi:10.1016/j.physa.2013.04.029

[39] Averill, J.D., Mileti, D., Peacock, R., Kuligowski, E., Groner, N., Proulx, G., Reneke, P., Nelson, H.: Federal investigation on the evacuation of the World Trade Center on September 11, 2001. In: Pedestrian and Evacuation Dynamics 2005, pp. 1-12 (2005). doi:10.1007/978-3-540-47064-9_1

[40] Braga, H.C., Moita, G.F., Almeida, P.E.M.: Can the average distance to be covered to the nearest exit be used as a complementary safety parameter in a building? In: Pedestrian and Evacuation Dynamics 2016, pp. 408-412 (2016)

[41] Low, D.J.: Statistical physics: following the crowd. Nature 407, 465-466 (2000). doi:10.1038/35035192

[42] Aik, L.E.: Exit-selection behaviors during a classroom evacuation. International Journal of Physical Sciences 6(13), 3218-3231 (2011)

[43] Seyfried, A., Passons, O., Steffen, B., Boltes, M., Rupprecht, T., Klingsch, W.: New insights into pedestrian flow through bottlenecks. Transportation Science 43(3), 395-406 (2009). doi:10.1287/trsc.1090.0263

[44] Carlo, U.: The safety against fire in Brazil. In: The Safety Against Fire in Brazil. [in portuguese], pp. 9-17. Projeto Editora (2008). doi:10.13140/2.1.1133.5680

[45] Brentano, T.: Emergency exits. In: The Protection Against Fire in Buildings Design. [in portuguese], pp. 159-282. Telmo Brentano (2010) 
[46] Silva, V.P., Pannoni, F.D., Ono, R.: The training of professionals in the area of fire safety. In: The Safety Against Fire in Brazil. [in portuguese], pp. 429-430. Projeto Editora (2008). doi:10.13140/2.1.1133.5680

[47] Vilar, E., Rebelo, F., Noriega, P., Duarte, E., Mayhorn, C.B.: Effects of competing environmental variables and signage on route-choices in simulated everyday and emergency wayfinding situations. Ergonomics 57(4), 511-524 (2014). doi:10.1080/00140139.2014.895054

[48] Dachner, G.C., Kinateder, M.: Effects of visual information on decision making during way-finding in emergency and non-emergency situations. In: Pedestrian and Evacuation Dynamics 2016, pp. 185-189 (2016)

[49] Haghani, M., Sarvi, M., Shahhoseini, Z., Boltes, M.: How simple hypothetical-choice experiments can be utilized to learn humans navigational escape decisions in emergencies. PLos ONE 11(11), 1-24 (2016). doi:10.1371/journal.pone.0166908 